\title{
Possibilities of Reducing Energy Costs in the Life Cycle of Office Buildings
}

\author{
Edyta Plebankiewicz, Krzysztof Zima and Damian Wieczorek
}

\author{
Department of Construction Management, Faculty of Civil Engineering, Cracow University of \\ Technology, Warszawska 24 St., 31-155 Kraków, Poland, eplebank@L3.pk.edu.pl
}

\begin{abstract}
Buildings absorb energy at every stage of the life cycle. The paper analyses the phases of the life cycle of an office building indicating the possibilities of reducing energy consumption. In particular, attention was paid to the most energy-intensive phase, that is the use phase. Both simple actions and more advanced solutions allowing to reduce the energy demand of a building during the use phase are characterized. For an exemplary office building, life cycle costs were calculated taking into account selected solutions improving energy efficiency.
\end{abstract}

Keywords: Life Cycle Cost, Office Buildings, Energy.

\section{Introduction}

Buildings are the largest energy consumer in Europe, utilizing about $40 \%$ of final energy, of which more than 55\% is used for room heating and cooling. At the same time, it is estimated that about one third of the world's energy consumption is related to the use of office and residential buildings. An additional problem is that most of this energy is supplied from nonrenewable sources, which contributes to environmental degradation and significant heating/cooling costs (Arendt et al., 2015). It should also be remembered that oil and gas resources are limited and no longer so readily available (Firląg, 2018).

The aim of the paper is to analyse the possibility of reducing energy consumption in office buildings in all phases of their life cycle.

\section{Energy Consumption of Buildings in the Various Life Cycle Phases}

From the point of view of energy consumption and environmental impact, the life cycle of a building involves the following phases:

- the manufacturing the products necessary for the construction of the building,

- the construction of the building,

- the use of the building,

- the end of the life cycle.

Each of these phases entails energy demand. Detailed modules related to energy demand, being part of particular phases of the building life cycle are depicted in Table 1 .

The energy consumption in the different phases of a building's life cycle depends on many factors. However, in general, when analysing the energy consumption of buildings in Poland, it is estimated that at the stage of construction of a building the energy consumption amounts to about $10 \%$, at the stage of use (with implementation performed according to the current standards) - to about $72 \%$, for the needs of renovation - to about $15 \%$ and for the demolition of the building - from 1 to $3 \%$ of the total accumulated energy demand in relation to the life cycle of the building, as illustrated in Figure 1. 
Table 1. Phases of the building life cycle.

\begin{tabular}{ll}
\hline \multicolumn{1}{c}{ Life cycle phase } & \multicolumn{1}{c}{ Life cycle modules } \\
\hline A - Product phase & A1 - Extraction and manufacture of raw materials \\
\cline { 2 - 2 } & A2 - Transport \\
\hline B - Construction phase & B - Manufacturing the product \\
\cline { 2 - 2 } C - Operation phase & B2 - Construction \\
\cline { 2 - 2 } & C1 - Usage \\
\cline { 2 - 2 } & C2 - Maintenance \\
\cline { 2 - 2 } & C4 - Repair \\
\cline { 2 - 2 } & C5 - Replacement \\
\hline D - End of life cycle phase & D1 - Demolition \\
\hline & D2 - Transport \\
\hline & D3 - Recycling/reuse \\
\hline
\end{tabular}
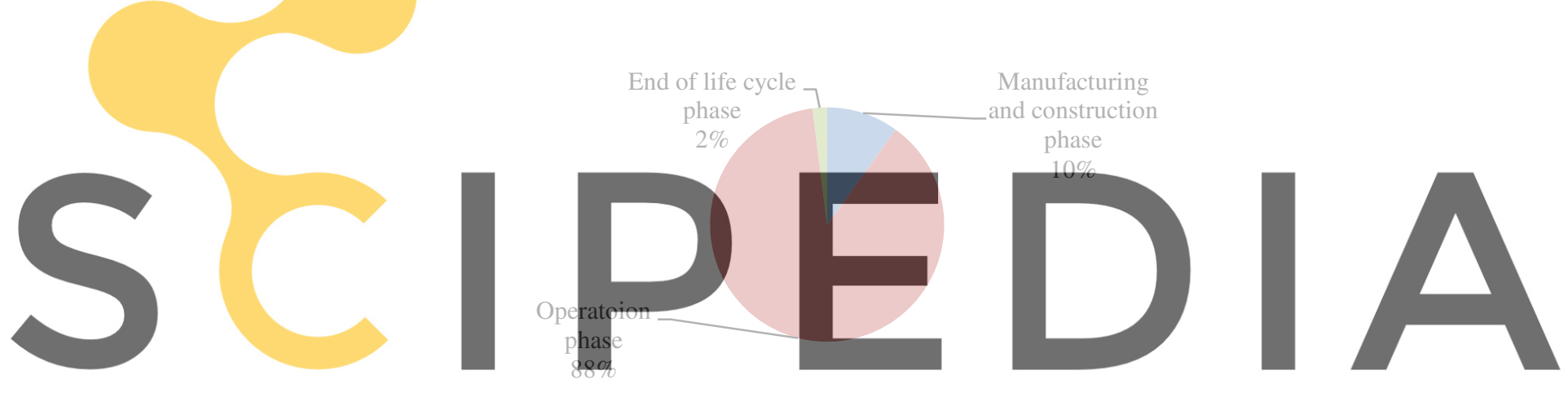

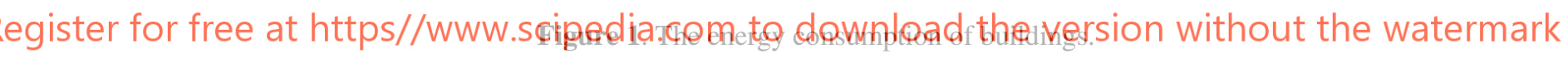

Since the greatest amount of energy is consumed in the operation phase of the building, therefore this issue is addressed mainly in the present paper.

However, the other phases cannot be ignored. In general, the energy consumed by the building include the following:

- embedded energy, that is energy accumulated in the building during its construction in the form of energy used for the production of materials, transport (A - product phase), building-in processes ( $\mathrm{B}$ - construction phase) and energy necessary to perform repairs and maintenance $(\mathrm{C}$ - operation phase);

- operational energy, namely energy used for heating, ventilation, air conditioning, lighting and energy ( $\mathrm{C}$ - operation phase);

- processing energy, meaning energy necessary for the demolition of the facility and waste management (D - end of life cycle phase).

The first phase of the building life cycle is related to the manufacturing building materials and products necessary for the construction of the building. According to the Guide of the Building Research Institute (Adamus, 2014), approximately three billion tonnes of raw 
materials are used each year for the production of building materials, which accounts for 40$50 \%$ of global production. Characteristically of the construction industry, it is estimated that it uses more than 10000 different types of materials, many of which are obtained through the exploitation of non-renewable resources. Table 2 shows the amount of embedded energy for common building materials, as revealed by European and US sources.

Table 2. The amount of embedded energy for common building materials.

\begin{tabular}{lcc}
\hline \multirow{2}{*}{ Material } & \multicolumn{2}{c}{ Embedded energy in MJ/kg, according to: } \\
\cline { 2 - 3 } & European sources & US sources \\
\hline naturally dried wood & 0.5 & $0.3 \div 1.1$ \\
\hline processed wood & $8 \div 24$ & $8 \div 24$ \\
\hline plastic materials & $80 \div 110$ & $55 \div 120$ \\
\hline local stone & $5 \div 6$ & 0.8 \\
\hline prefabricated concrete & 2 & $2.5 \div 7$ \\
\hline ceramics & $2.5 \div 8$ & $14 \div 30$ \\
\hline glass & $12 \div 26$ & \\
\hline
\end{tabular}

Table 3 depicts the amount of energy associated with the transport of building materials. As can be seen from this summary, the largest energy consumption is in road transport.

Table 3. The amount of energy associated with the transport of building materials.
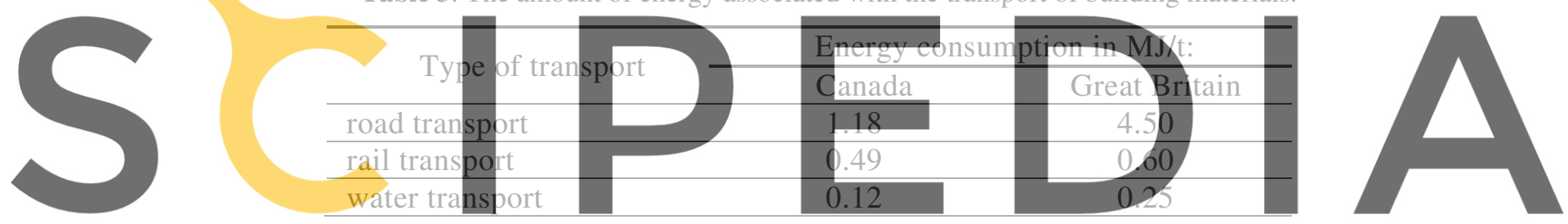

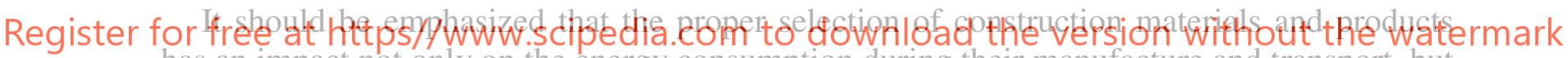

has an impact not only on the energy consumption during their manufacture and transport, but also on the energy demand in the operation phase, related to the need for repairs and renovations which are largely dependent on the characteristics of the material itself.

In general, the amount of the embedded energy of a building can be minimised by applying the following principles:

- design of objects with a long service life, made of durable materials and not requiring repair or overhaul;

- ensuring that the different materials can be easily separated from each other for repair and demolition;

- the use of locally available materials;

- the use of materials with a high recycling rate;

- avoidance of materials generating troublesome waste;

- minimising the use of highly energy-intensive materials;

- preference for renewable energy materials,

- the use of materials that reduce energy consumption during the operation of the building, which indicates the choice of sustainable materials. 


\section{Energy Consumption in Office Buildings at the Operation Stage}

In every building, by far the highest energy consumption occurs during the operation phase. A specific feature of such buildings as commercial facilities is that their energy consumption per square metre is on average $40 \%$ higher than that of residential buildings. Their electricity consumption is particularly high, due to complex lighting, air conditioning or ventilation systems. Also, the climate in countries such as Poland, for example, means that in standard buildings the heating season lasts $220-240$ days a year, hence $70 \%$ of energy in buildings is used for heating and cooling.

Moreover, in comparison to other buildings, modern office facilities have a specific consumption of electricity associated with their high demand for energy needed to power computer and other office equipment. Figure 2. illustrates the energy consumption of an average office building in 2012. The data comes from the research conducted by an institution established in the USA, dealing with the collection and analysis of data on energy issues: the U.S. Energy Information Administration.
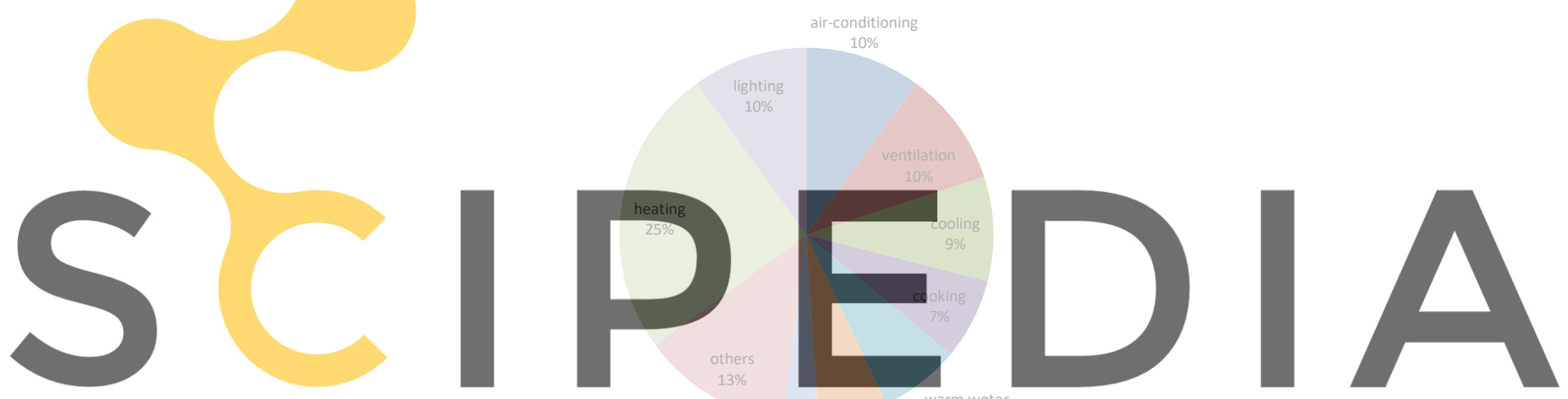

\section{Register for free at https//www.scipedia.com to downlice equment the version without the watermark}

Figure 2. Energy consumption of a commercial building in 2012.

As Figure 2. reveals, the highest energy consumption in 2012 was due to the demand for heating of the building, while the power supply of office equipment and computers accounted for less than $9 \%$ of its total consumption. Moreover, forecasts for 2050 show that although demand for energy for heating and lighting in office buildings, for example, will decrease significantly, energy demand for computer hardware and other office equipment will increase by more than $20 \%$ (Figure 3 ).

Such specificity of office buildings should probably be one of the important factors when considering the possibility of reducing energy consumption. This does not mean, however, that no action should be taken to reduce the energy required for heating, cooling or ventilation. 


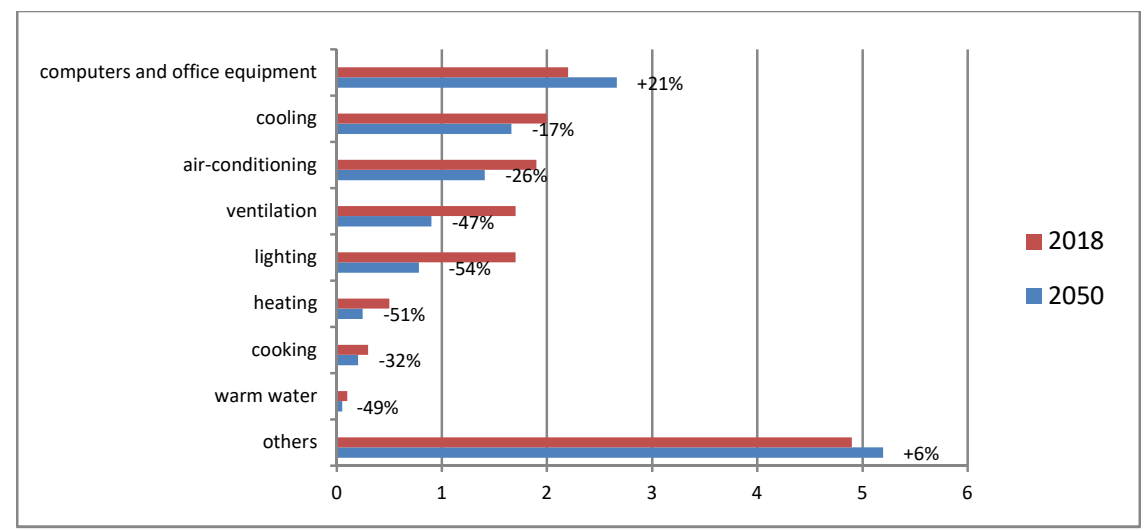

Figure 3. Current and planned energy consumption in office buildings (kilowatt hours per 1square foot).

\section{Opportunities for the Reduction of Energy Consumption}

\section{Research results indicate that almost $75 \%$ of buildings are low energy efficient, which means} that there is still significant potential for rational energy savings in buildings. According to the European Commission, a statistical building in the European Union countries consumes 15-25\% more energy than it needs. In Poland, on the other hand, energy consumption in buildings is more than twice as high as in other EU countries. The Polish economy is also about 2.7 times more en ergy-intensive than in the European Union and 5 times more so than in Japan. Improvement for the coming decades

Actions reducing an as well as more advance
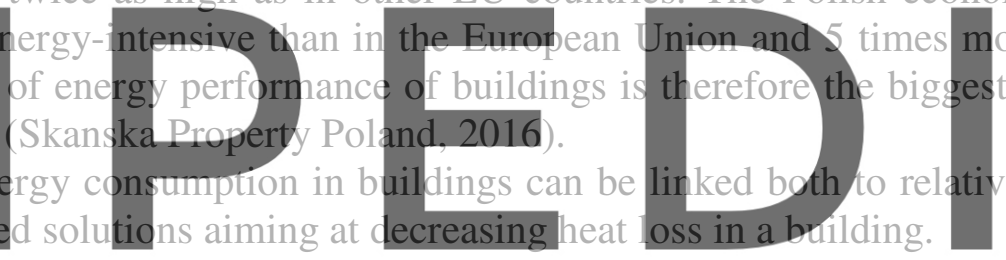

It can be observed that the largest heat losses in a building are related to the heat transfer

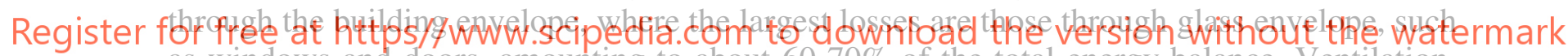
as windows and doors, amounting to about 60-70\% of the total energy balance. Ventilation, on the other hand, causes losses of 30-40\%. Therefore, it is necessary to minimize heat losses, while maximizing the use of energy gains.

Heat losses can be reduced by the following improvements in (Ministry of Investment and Economic Development in Poland, 2018):

- ventilation - application of mechanical ventilation with heat recovery (recuperation) and high tightness of the building,

- windows and doors - use of energy-saving woodwork,

- external walls - appropriate wall insulation,

- roof - appropriate roof insulation,

- floors on the ground - adequate insulation of the floor on the ground,

- thermal bridges - use of solutions minimizing the occurrence of thermal bridges.

In the case of existing buildings, this will involve thermal upgrading, such as replacing window frames, replacing central heating systems, or optimising heating by insulating hot water pipes, heat and small heat pump systems in the radiator. A simple change in habits can also lead to a reduction in energy consumption, such as (Kopietz-Unger, 2012):

- appropriate setting of air temperature in rooms, up to approx. $10 \%$, 
- exposing the radiators, about $10 \%$,

- lowering the temperature of domestic hot water to approx. $6.6 \%$,

- use of aerators, approx. $8 \%$,

- the change from rib radiators to convection heaters, about $14 \%$.

More complex solutions include the use of alternative solutions for heating water or building interiors. The increased use of alternative energy sources contributes to the development of low-carbon energy sources. Such solutions include the efficient use of solar collectors to heat water. Studies on the benefits of using natural energy sources, in particular solar panels, are presented in (Kale et al., 2018). The following conclusions can be drawn from the project:

- energy-saving approach to the solar collector system requires an initial investment of 1.3$16 \%$,

- with minimal initial investment in solar panels, one can save $4.3 \%$ of the total cost within 30 years

- with the proposed solar panel, 54 - 64\% of the total cost can be saved within 25 years.

The use of solar systems can be effectively used to cool rooms. The solar system absorbs solar radiation and converts it into heat energy, which is subsequently transferred to a cooling exchanger and then to a central heating system for cooling.

An interesting solution is the use of photovoltaic cells to produce electricity. In Poland, from $1 \mathrm{~m} 2$ of solar cells it is possible to obtain up to $100 \mathrm{kWh}$ of electricity. The condition is that the generated energy will not be used for water heating and heating purposes
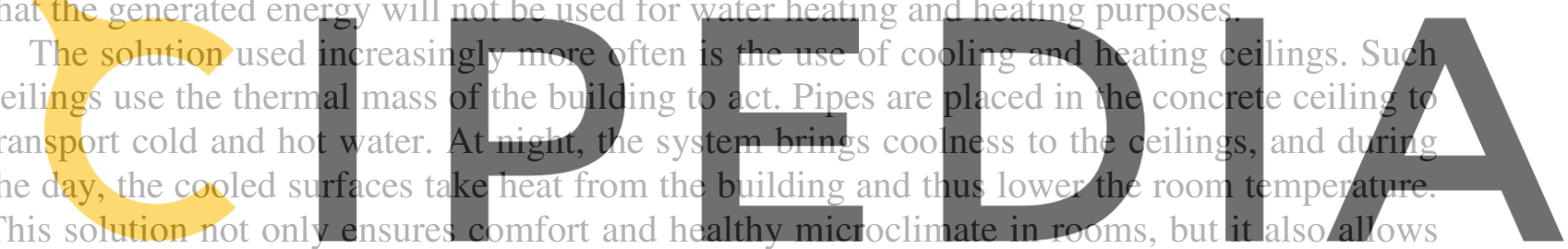

to reduce energy consumption. Unlike traditional air-conditioning systems, they operate in

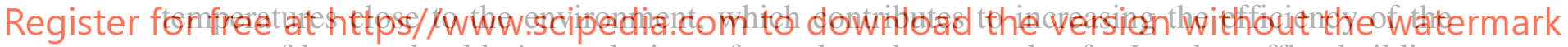
source of heat and cold. An analysis performed on the example of a London office building with a total area of $1000 \mathrm{~m} 2$ showed that this type of ceiling provides annual savings of between 12 and $31 \%$ compared to conventional installations in the form of fan coil units, displacement ventilation or chilled beams of similar capacity. Manufacturers assure that the investment costs are low, with savings of 10-30\% compared to conventional air conditioning systems and low maintenance and service costs up to $30 \%$, compared to conventional air conditioning systems.

Modern office buildings contain rooms of a different character, such as: halls and reception areas, atria, server rooms, engine rooms, garages, offices, conference rooms, restaurants, retail and service premises. Each of them requires a separate system to guarantee different levels of comfort and safety. In order for all these elements to constitute a coherent and wellfunctioning whole, advanced automatic control and regulation systems, BMS (Building Management System), should be applied in office buildings, which in some cases are supplemented with functionalities allowing for energy consumption management, that is BEMS (Building Energy Management Systems). Their basic function is to ensure proper indoor environment parameters (user comfort) with rational energy consumption. According to the data from Distech Controls Inc., the manufacturer of building automation systems, 
Building management systems never cost more than $1 \%$ of their value. However, on average $45 \%$ of energy consumption depends on their quality, that is $25 \%$ of the value of the investment over the 30 years of the life cycle of the building. Depending on the type of the building, lighting consumes $30-40 \%$ of the electricity, of which $10-58 \%$ can be saved. Over $65 \%$ of energy costs is absorbed by heating and air conditioning, and potential savings amount to $8-45 \%$.

\section{Cost-Benefit Analysis of Solutions that Improve the Energy Efficiency Standard of an Office Building}

Simulations concerning analyses and benefits resulting from energy-saving construction were performed by the Polish National Energy Conservation Agency on the example of buildings of different purpose (Węglarz, 2017). One of the buildings under analysis was an office building. The model office facility selected for the analysis was a 6-storey building with a usable area of $2124 \mathrm{~m}^{2}$. On the basis of simulations and additional own analyses, the authors performed calculations which enabled the assessment of costs and benefits resulting from the application of solutions that increase the energy efficiency of the office building.

For standard buildings, the classic and most frequently used installation solutions were adopted, that is water heating systems with convector heaters and boilers for coal, natural gas, fuel oil, LPG or the application of a heat substation with a connection to a district heating network. In a high standard building, it was assumed that, in comparison to a standard building, the insulation thickness of the envelope was increased by $20 \mathrm{~cm}$ and that windoys
with a penetration coefficient of $0.5 \mathrm{~W}\left(\mathrm{~m}^{2} \cdot \mathrm{K}\right)$ were used.
In addition, for the model building with energy-saving standards, the following were
applied: higher thickness of pipeline thermal insulation, better quality control valve and
thermo-valves, water-saving fittings in the hot water installation and mechanical ventilation with heat recovery of $85 \%$. For the building with collectors, the use of flat solar collectors

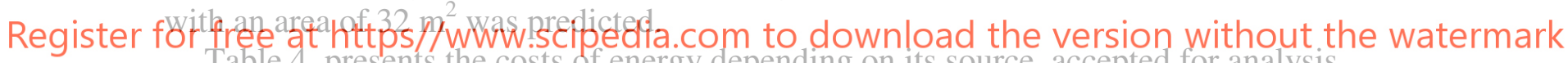
Table 4. presents the costs of energy depending on its source, accepted for analysis.

Table 4. Energy costs depending on the source of energy (Węglarz, 2017).

\begin{tabular}{lcc}
\hline \multirow{2}{*}{ Source of energy } & \multicolumn{2}{c}{ External costs } \\
\cline { 2 - 3 } & EUR/MWH & EUR/GJ \\
\hline Coal & 11.00 & 3.06 \\
\hline GZ50 & 0.42 & 0.12 \\
\hline Electricity & 57.00 & 15.83 \\
\hline Fuel oil & 1.54 & 0.43 \\
\hline LPG & 1.54 & 0.43 \\
\hline Network heat & 10.40 & 2.89 \\
\hline
\end{tabular}

The results of simulation analyses for an office building and coal heating are presented in Table 5 . 
Table 5. Results of simulation analyses for an office building for coal heating

\begin{tabular}{lccc}
\hline & $\begin{array}{c}\text { construction cost } \\
\text { [EUR] }\end{array}$ & $\begin{array}{c}\text { Annual energy } \\
\text { cost [EUR/year] }\end{array}$ & $\begin{array}{c}\text { LCC [EUR] } \\
\text { (30 year; r=5\%) }\end{array}$ \\
\hline Standard building & 1373692 & 8428 & 1915361 \\
\hline $\begin{array}{l}\text { High-standard building with } \\
\text { cooling and heating ceilings }\end{array}$ & 1432377 & 6730 & 1900120 \\
\hline $\begin{array}{l}\text { High standard building with } \\
\text { collectors }\end{array}$ & 1506222 & 1966 & 1868795 \\
\hline $\begin{array}{l}\text { High standard building with heat } \\
\text { pump }\end{array}$ & 1536054 & 2096 & 1731453 \\
\hline
\end{tabular}

\section{Conclusions}

Buildings absorb energy to varying degrees at every stage of their life cycle. By far the greatest demand for energy occurs during the operation phase of a building. Reducing energy consumption during this phase is necessary for both economic and environmental reasons.

The life cycle cost analysis of an office building conducted in the present paper showed the effectiveness of the use of cooling and heating ceilings, solar collectors and heat pumps.

\section{ORCID}

Edyta Plebankiewicz: http://orcid.org/0000-0003-0892-5027

Krzysztof Zima: http://orcid.org/0000-0001-5563-5482

Damian Wieczorek: http://orc

References

Adamus, E. (2014). Zrónnoważone budownictwo w U Budowlanej.

Arendt, K., Krzaczek, M., Antczak, R. and Tejchman, J. (2015). Wpływ systemu ogrzewania na zużycie energii i koszty eksploatacyjne budynku (in Polish). Przeglad Budowlany, 4, 46-50.

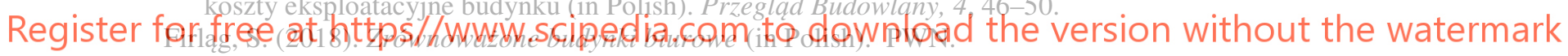

Kale, N.N., Joshi, D. and Menon, R. (2016). Life cycle cost analysis of commercial buildings with energy efficient approach. Perspectives in Science, 8, 452-454. DOI:https://doi.org/10.1016/j.pisc.2016.04.102.

Kopietz-Unger, J. (2012). Zmniejszenie zapotrzebowania na energię poprzez wzrost efektywości energetycznej budynku i działania prosumenckie (in Polish). Przegląd Budowlany, 12.

Ministry of Investment and Economic Development in Poland (in Polish). (2018). Poradnik w zakresie poprawy charakterystyki energetycznej budynków, Warszawa

Royal Institution of Chartered Surveyors (RICS). (2016). Life cycle costing: RICS professional guidance.

Skanska Property Poland, report (in Polish). , (2016). Zużycie energii w budynkach biurowych.

US Energy Information Administration https://www.eia.gov/

Węglarz, A. (2017). Nakłady finansowe i korzyści wynikające z budowy różnych typów budynków energooszczędnych (in Polish). Krajowa Agencja Poszanowania Energii S.A.

www.argox.com.pl/budownictwo_zrownowazone.php

www.instalacjebudowlane.pl/7894-23-53-stropy-chlodzace-grzewcze-uponor.html 